\title{
PSIKOEDUKASI PROTOKOL KESEHATAN DALAM MENCEGAH PENYEBARAN COVID-19 DI DESA BANDING AGUNG
}

\author{
Sawi Sujarwo, Anggita Nadia Try Buana, Mulia Marita \\ Program Studi Psikologi, Fakultas Psikologi Universitas Bina \\ Darma,Indonesia \\ Email : trybuanaanggitanadia@gmail.com
}

\begin{abstract}
ABSTRACK
Psychoeducation is a process of providing psychological understanding or education to individuals or groups. Corona viruses are a family of viruses found in humans and animals. Most of the viruses can infect humans and cause various kind of diseases starting from common illnesses such as the flu, to more fatal diseases, such as Middle East Respiratory Syndrome (MERS) and Severe Acute Respiratory Syndrome (SARS). The purpose of this community dedication is to provide understanding and education about the importance of wearing masks, washing hands, and consuming healthy food, motivating the people to pay attention to health during this covid-19 pandemic. The method of expressing deep in psychoeducation is carried out directly such as providing counseling, and also through intermediary print media banner installation. The target of this activity is the general public of Banding Agung Village. The results from this psychoeducation are that most residents are motivated to keep up health and taking vitamins and food that's healthy and nutritious foods, and Increased insight and knowledge about the importance of Stay healthy during the COVID-19 pandemic.
\end{abstract}

Keywords : Scientific articles,Psychoeducation,Research result 


\begin{abstract}
ABSTRAK
Psikoedukasi adalah sebuah proses pemberian pemahaman atau pendidikan psikologis pada individu atau kelompok. Virus corona adalah sebuah keluarga virus yang ditemukan pada manusia dan hewan. Sebagian virusnya dapat menginveksi manusia serta menyebabkan berbagai penyakit mulai dari penyakit umum seperti flu, hingga penyakit-penyakit yang lebih fatal, seperti Middle East Respiratory Syndrome (MERS) dan Serve Acute Respiratory Syndrome (SARS). Tujuan dari pengabdian masyarakat ini adalah Memberikan pemahaman serta edukasi tentang pentingnya memakai masker, mencuci tangan, dan mengkonsumsi makanan sehat, memotivasi masyarakat untuk memperhatikan kesehatan di saat pandemi covid-19 ini. Metode penyampaian dalam psikoedukasi ini dilakukan secara langsung seperti memberi penyuluhan, dan juga melalui perantara media cetak pemasangan banner. Sasaran kegiatan ini merupakan masyarakat Desa Banding Agung. Hasil dari psikoedukasi ini adalah Sebagian besar warga sudah termotivasi untuk menjaga kesehatan dan mengkonsumsi vitamin dan makanan yang sehat dan bergizi, dan Bertambahnya wawasan dan pengetahuan tentang pentingnya menjaga kesehatan di tengah pandemi covid-19.
\end{abstract}

Kata Kunci : Artikel Ilmiah,Psikoedukasi,Hasil Penelitian

Psikoedukasi Protokol Kesehatan dalam Mencegah Penyebaran Covid-19 di Desa Banding Agung 


\section{A. PENDAHULUAN}

Virus Corona atau Corona Virus Disease pada tahun 2019 (COVID-19) menjadi permasalahan global yang cukup serius, Virus Corona merupakan wabah yang saat ini sedang melanda banyak negara di dunia. Virus ini menyerang sistem pernafasan manusia dan menyebabkan infeksi pada saluran pernafasan. Gejala virus ini yaitu flu biasa hingga penyakit yang serius seperti Middle East Respiratory Syndrom (MERS) dan Severe Acute Respiratory Syndrom (SARS). Virus Corona merupakan jenis virus baru yang ditemukan pertama kali di Wuhan Cina tahun 2019, kemudian diberi nama Severe Acute Respiratory Syndrom Coronavirus Disease-2019 (COVID-19). Gejala Virus Corona mirip dengan SARS, Jika dilihat dari persentase angka kematian, kasus kematian akibat SARS $(9,6 \%)$ lebih tinggi dibanding COVID-19 (Kurang dari 5 \%). Meskipun demikian jumlah kasus COVID-19 lebih banyak dibanding SARS, COVID19 juga mempunyai penyebaran yang cepat dan luas dibanding SARS (Aslamiyah dan Nurhayati 2021)

Penyebaran COVID-19 yang cukup luas membawa banyak dampak bagi masyarakat dan terkhusus pasien COVID-19 sendiri. Salah satu dampaknya ialah kehilangan nyawa, penurunan ekonomi, terkendala aktivitas pendidikan, dan sosial. Serta yang paling mengkhawatirkan ialah dampak psikologis dan perubahan prilaku masyarakat. Virus ini tidah hanya mempengaruhi kondisi fisik namun juga pada kesehatan mental dan kualitas hidup dari pasien (Aslamiyah dan Nurhayati 2021)

Hasil penelitian Huljanah et al., (2020) menunjukkan bahwa banyak masyarakat belum mematuhi PSBB atau peraturan protokol 
kesehatan yang telah dibuat oleh pemerintah. Pemahaman dan kesadaran serta tingkat kepatuhan Social distance masyarakat masih rendah. masih terlihat warga beraktivitas ke luar rumah untuk tujuan rekreasi, bergerombol, berkumpul tanpa menggunakan masker ataupun menjaga jarak (Sofianto 2021)

Psikoedukasi Menurut Supraktiknya, psikoedukasi sering disebut pendidikan pribadi dan pendidikan sosial. Psikoedukasi adalah kegiatan yang dilakukan untuk meningkatkan pemahaman dan/atau keterampilan sebagai usaha pencegahan dari munculnya dan/atau meluasnya gangguan psikologis di suatu kelompok, komunitas atau masyarakat serta kegiatan yang dilakukan untuk meningkatkan pemahaman bagi lingkungan terutama keluarga (Kamil dan Qamaria 2021)

Psikoedukasi adalah suatu intervensi yang dapat dilakukan pada individu, keluarga, dan kelompok yang fokus pada mendidik partisipannya mengenai tantangan signifikan dalam hidup, membantu partisipan mengembangkan sumber-sumber dukungan dan dukungan sosial dalam menghadapi tantangan tersebut bahkan mengembangkan keterampilan coping untuk menghadapi tantangan tersebut. Berdasarkan pengertian tersebut dapat ditarik kesimpulan bahwa fokus dari psikoedukasi yaitu: (a) Mendidik partisipaan mengenai tantangan dalam hidup, (b) Membantu partisipan mengembangkan sumber-sumber dukungan dan dukungan sosial dalam menghadapi tantangan hidup,(c) Mengembangkan keterampilan coping untuk menghadapi tantangan hidup. (d) Mengembangkan dukungan emosional, (e) Mengurangi sense of stigma dari partisipan. (f) Mengubah sikap dan belief dari partisipan terhadap suatu gangguan (disorder). (g) Mengidentifikasi dan mengeksplorasi perasaan terhadap suatu isu. (h) Mengembangkan

Psikoedukasi Protokol Kesehatan dalam Mencegah Penyebaran Covid-19 di Desa Banding Agung 
keterampilan penyelesaian masalah. (i) Mengembangkan keterampilan crisisintervention (Anwar dan Rahmah 2017)

Psikoedukasi merupakan pengembangan dan pemberian informasi dalam bentuk pendidikan masyarakat sebagai informasi yang berkaitan dengan psikologi sederhana atau informasi lain yang mempengaruhi kesejahteraan psikososial masyarakat. Pemberian informasi ini bisa memperguanakan berbagai media dan pendekatan. Psikoedukasi bukan merupakan pengobatan, namun merupakan suatu terapi yang dirancang untuk menjadi bagian dari rencana perawatan secara holistik. Melalui psikoedukasi, pengetahuan mengenai diagnosis penyakit, kondisi pasien, prognosis dan lain-lain dapat ditingkatkan. Terapi psikoedukasi mengandung unsur peningkatan pengetahuan konsep penyakit, pengenalan dan pengajaran teknik mengatasi gejala-gejala penyimpangan perilaku, serta peningkatan dukungan bagi pasien. Adapun komponen latihan dapat berupa keterampilan komunikasi, latihan penyelesaian konflik, latihan asertif, latihan mengatasi perilaku kecemasan (Sutinah 2020)

Psikoedukasi diberikan dalam bentuk informasi sistematis, terstruktur, didaktik tentang penyakit dan pengobatannya, termasuk mengintegrasikan aspek emosional yang memungkinkan individu untuk mengatasi penyakit. Model yangumum dikembangkan adalah psikoedukasi dengan model informasi, yang menyediakan pengetahuan untuk meningkatkan kesadaran kelompok tentang penyakit dan kontribusi pada manajemen penderita (Srivastava dan Panday 2016)

Menurut Walsh psikoedukasi dapat mengajarkan seseorang menghadapi masalah sehingga mampu menurunkan stress yang terkait dengan masalah yang dihadapi dan mencegah agar tidak terjadi kembali. 
Psikoedukasi juga didasarkan pada kekuatan partisipan dan lebih fokus pada saat ini dan masa depan daripada kesulitan kesulitan masa lalu. Dibanding dengan intervensi yang lainnya, psikoedukasi lebih fokus pada sistem yang lebih besar dan mencoba untuk tidak mempatologikan pasien.Psikoedukasi tidak hanya memberikan informasi-informasi penting atau pengetahuan yang terkait dengan permasalahan yang dihadapi, tetapi juga mengajarkan ketrampilan ketrampilan yang dapat dianggap penting untuk menghadapi situasi permasalahan (Noviyanti dan . 2019)

Tujuan dari program psikoedukasi adalah menambah pengetahuan tentang permasalahan yang sedang dihadapi oleh klien dan meningkatkan fungsinya dalam lingkungan. Metode penyampaian dalam psikoedukasi bisa secara langsung seperti memberi penyuluhan, bisa pula melalui perantara media baik media cetak maupun elektronik.

Menurut Suny \& Win-King terapi psikoedukasi keluarga sangat efektif karena memberikan informasi tentang prefentif dan promotif, ketrampilan koping, kognitifn tingkah laku dan ketrampilan bagi keluarga. psikoedukasi terhadap keluarga dapat meningkatkan kemampuan kognitif karena dalam terapi mengandung unsur untuk meningkatkan pengetahuan keluarga tentang penyakit, mengajarkan teknik yang dapat membantu keluarga untuk mengetahui gejala-gejala penyimpangan perilaku, serta peningkatan dukungan bagi anggota keluarga itu sendiri (Wiyati, Wahyuningsih, dan Widayanti 2010)

Permasalahan yang terjadi dalam kegiatan ini adalah kurangngnya antusias masyarakat desa Banding Agung sekitar untuk menjalankan protokol kesehatan.masyarakat Desa masih banyak berpergian kepasar,kekebun dan keluar rumah tanpa menggunakan masker atau

Psikoedukasi Protokol Kesehatan dalam Mencegah Penyebaran Covid-19 di Desa Banding Agung 
penutup mulut. Maka dari itu saya ingin mengajukan program kerja saya dengan meningkatkan suatu dorongan motivasi untuk masyarakat sekitar berupa edukasi atau sosialisasi tentang protokol kesehatan dan mencegah penyebaran covid-19.

Pengembangan desa, sebagai salah satu kegiatan pembangunan, diupayakan dapat sejalan dengan konsep dan prinsip pembangunan berkelanjutan, dengan menerapkan diantaranya pengembangan motivasi atau pemahaman kepada masyarakat desa banding agung.Tentu upaya ini dalam rangka memperkuat dan mewujudkan kemandirian dan kesejahteraan masyarakat desa (Alfani dkk. 2019)

Sasaran kegiatan ini merupakan masyarakat Desa Banding Agung. Desa Banding Agung ini terletak di kecamatan Banding Agung, Kabupaten Oku Selatan , Provinsi Sumatera Selatan. Kemudian diadakan nya Kuliah Kerja Nyata Tematik (KKN-T) dengan judul "Psikoedukasi Protokol Kesehatan Dalam Mencegah Penyebaran Covid19 Di Desa Banding Agung”

Menurut Sumampouw Kebijakan-kebijakan yang dikeluarkan diharuskan dapat mengurangi permasalahan yang sudah ada, Setidaknya upaya memberantas epidemi maupun pandemi di Indonesia dilakukan melalui tindakan-tindakan, seperti: kewaspadaan diri, penanganan terhadap penderita, sumber penyakit harus dimusnahkan, dan sosialisasi kepada masyarakat. Upaya-upaya yang sistematis yang dilakukan diantaranya adalah perencanaan gerakan skala nasional pemberantasan penyakit dan perjanjianperjanjian skala regional maupun internasional (Wahidah dkk. 2020)

Permasalahan pada program kuliah kerja nyata tematik ini adalah Sebagian besar masyarakat di Desa Banding Agung tidak sadar atau 
masih menyepelekan adanya virus Covid-19,Sebagian besar masyarakat banyak tidak menggunakan masker saat berpergian keluar rumah,kebun,kepasar, Masyarakat perlu Motivasi sebagai pengembangan Kognitifnya untuk lebih mengetahui tentang apa itu virus corona/covid-19, Mengembangkan kesadaran masyarakat akan pentingnya menjalani protokol kesehatan untuk memutus tali rantai penyebaran covid-19.

\section{B. PELAKSANAAN DAN METODE}

Belakangan ini Indonesia mengalami pandemi covid-19 dimana pemerintah menganjurkan untuk selalu menerapkan protokol kesehatan di masa pandemi tersebut. Upaya untuk melakukan pembangunan atau perubahan ke masyarakat desa banding agung ini dengan cara melakukan penyuluhan atau memberika psikoedukasi ke masyarakat desa banding agung. Berikut adalah tabel kegiatan dilakukan penyuluhan psikoedukasi di desa banding agung.

Tabel 1.

Waktu,Tempat dan Aktivitas pelaksanaan

\begin{tabular}{l|l|l|l|l}
\hline No & Hari / Tanggal & Waktu & Tempat & Aktivitas \\
\hline 1. & $\begin{array}{l}\text { Rabu/28 Juli } \\
2021\end{array}$ & $\begin{array}{l}\text { 09.00 } \\
\text { WIB s/d } \\
\text { selesai }\end{array}$ & $\begin{array}{l}\text { Posko covid } \\
\text { Desa Banding } \\
\text { Agung }\end{array}$ & $\begin{array}{l}\text { Melakukan } \\
\text { Psikoedukasi dan } \\
\text { membagikan } \\
\text { masker ke warga } \\
\text { Banding Agung } \\
\text { yang datang ke } \\
\text { posko covid untuk } \\
\text { mengambil } \\
\text { bantuan. }\end{array}$ \\
\hline 2. & $\begin{array}{l}\text { Minggu/01 } \\
\text { Agustus 2021 }\end{array}$ & $\begin{array}{l}\text { WIB s/d } \\
\text { selesai }\end{array}$ & $\begin{array}{l}\text { Kantor balai } \\
\text { desa/kepala }\end{array}$ & $\begin{array}{l}\text { Membagikan } \\
\text { masker } \\
\text { melakukan dan }\end{array}$ \\
\hline
\end{tabular}

Psikoedukasi Protokol Kesehatan dalam Mencegah Penyebaran Covid-19 di Desa Banding Agung 


\begin{tabular}{|c|c|c|c|c|}
\hline & & & $\begin{array}{l}\text { desa banding } \\
\text { agung }\end{array}$ & $\begin{array}{l}\text { psikoedukasi ke } \\
\text { warga desa banding } \\
\text { agung. }\end{array}$ \\
\hline 3. & $\begin{array}{l}\text { Selasa/03 } \\
\text { Agustus } 2021\end{array}$ & $\begin{array}{l}16.00 \\
\text { WIB s/d } \\
\text { selesai }\end{array}$ & $\begin{array}{l}\text { Desa banding } \\
\text { agung }\end{array}$ & $\begin{array}{l}\text { Melakukan } \\
\text { Psikoedukasi ke } \\
\text { warga desa banding } \\
\text { agung. }\end{array}$ \\
\hline 4. & $\begin{array}{l}\text { Jumat/06 } \\
\text { Agustus } 2021\end{array}$ & $\begin{array}{l}15.30 \\
\text { WIB s/d } \\
\text { selesai }\end{array}$ & $\begin{array}{l}\text { Desa Banding } \\
\text { Agung }\end{array}$ & $\begin{array}{l}\text { Melakukan } \\
\text { Psikoedukasi dan } \\
\text { membagikan } \\
\text { masker ke warga } \\
\text { desa banding agung }\end{array}$ \\
\hline 5. & $\begin{array}{l}\text { Sabtu/07 } \\
\text { Agustus } 2021\end{array}$ & $\begin{array}{l}09.30 \\
\text { WIB s/d } \\
\text { selesai. }\end{array}$ & $\begin{array}{l}\text { Posko covid } \\
\text { Desa Banding } \\
\text { Agung }\end{array}$ & $\begin{array}{l}\text { Melakukan } \\
\text { Psikoedukasi ke } \\
\text { warga Banding } \\
\text { Agung yang datang } \\
\text { ke posko covid } \\
\text { untuk mengambil } \\
\text { bantuan. }\end{array}$ \\
\hline 6. & $\begin{array}{l}\text { Senin/09 } \\
\text { Agustus } 2021\end{array}$ & $\begin{array}{l}08.00 \\
\text { WIB s/d } \\
\text { selesai. }\end{array}$ & $\begin{array}{lr}\text { PAUD } & \text { IT } \\
\text { Azkia Desa } & \text { Danding } \\
\text { Agung } & \end{array}$ & $\begin{array}{l}\text { Membagikan susu } \\
\text { dan memberikan } \\
\text { motivasi ke anak } \\
\text { PAUD untuk } \\
\text { menerapkan } \\
\text { protokol kesehatan. }\end{array}$ \\
\hline 7. & $\begin{array}{l}\text { Selasa/10 } \\
\text { Agustus } 2021\end{array}$ & $\begin{array}{l}10.00 \\
\text { WIB s/d } \\
\text { selesai. }\end{array}$ & $\begin{array}{l}\text { Posko covid } \\
\text { Desa banding } \\
\text { agung }\end{array}$ & $\begin{array}{l}\text { Melakukan } \\
\text { Psikoedukasi ke } \\
\text { warga Banding } \\
\text { Agung yang datang } \\
\text { ke posko covid } \\
\text { untuk mengambil } \\
\text { bantuan. }\end{array}$ \\
\hline 8. & $\begin{array}{l}\text { Selasa/17 } \\
\text { Agustus } 2021\end{array}$ & $\begin{array}{l}10.30 \\
\text { WIB s/d } \\
\text { selesai }\end{array}$ & $\begin{array}{l}\text { Posko covid } \\
\text { Desa banding } \\
\text { agung }\end{array}$ & $\begin{array}{l}\text { Melakukan } \\
\text { Psikoedukasi ke } \\
\text { warga Banding } \\
\text { Agung yang datang } \\
\text { ke posko covid } \\
\text { untuk mengambil } \\
\text { bantuan. }\end{array}$ \\
\hline
\end{tabular}


Sesuai penelitian dengan permasalahan di desa banding agung berikut metode dan tahapan penerapan pengabdian kepada masyarakat desa banding agung sebagai berikut:

\section{Tahapan Kegiatan :}

a. Pengumpulan Data dan Literatur

Pengumpulan literature yang mendukung dilakukan pada tahap ini. Literatur-literatur diambil dari jurnal maupun internet serta sumbersumber lainnya yang terpecaya serta konsultasi dengan dosen pembimbing keilmuan.

b. Perancangan Alat

Dalam tahap ini dilakukan perancangan alat dan beberapa program kerja. Tahap perancangan alat ini dan program kerja dibagi menjadi :

1. Pembagian Masker.

2. Edukasi tentang covid-19.

3. Memotivasi masyarakat untuk mengkonsumsi makanan sehat.

4. Pemasangan banner gerakan hidup sehat.

5. Memotivasi dan meng edukasi masyarakat untuk menjalankan protokol kesehatan.

\section{Tahapan Persiapan}

Tahapan persiapan dilaksanakan selama kurang lebih satu minggu dan menyusun jadwal kegiatan penyuluhan, menentukan tempat penyuluhan yaitu dilingkungan masyarakat dengan melakukan edukasi saat ada kegiatan di kantor balai desa atau di posko covid-19 dan menyiapkan bahan untuk memberikan penyuluhan.

\section{Tahapan Pelaksanaan}

a. Penyuluhan

Psikoedukasi Protokol Kesehatan dalam Mencegah Penyebaran Covid-19 di Desa Banding Agung 
Pada tahap pelaksanaan yang pertama yaitu dengan dilakukannya memberikan edukasi kepada masyarakat tentang pentingnya menjalankan prokol kesehatan di tengah pandemi covid-19 ini.

b. Pengajaran

Pada tahap ini masyarakat diberikan pengetahuan dan wawasan tentang bahayanya pandemi jika tidak menjaga kesehatan .

\section{Tahapan Evaluasi}

Tahap evaluasi ini dilakukan untuk melakukan pemantauan pada masyarakat sekitar mengenai program yang diberikan tentang permasaalahan yang ada dan membuat masyarakat sadar akan pentingnya menjaga kesehatan dan menjalankan protokol kesehatan di tengah paandemi covid-19. Model atau instrument yang digunakan adalah dengan melakukan psikoedukasi protokol kesehatan ke masyarakat desa banding agung dan membagikan masker serta ikut membantu polindes memberikan layanan kesehatan ke masyarakat desa banding agung.

\section{HASIL DAN PEMBAHASAN}

Kegiatan KKNT (Kuliah Kerja Nyata Tematik) yang kami laksanakan berlangsung selama 1 bulan, yang dimulai dari 26 Juli 2021 sampai dengan 26 Agustus 2021. Pada kegiatan KKNT ini berfokus pada psikoedukasi protokol kesehatan di masa pandemi yang dilakukan di desa banding agung.

\section{Tabel 2.}

Analisis Log Frame dari hasil yang dicapai

\begin{tabular}{c|l|l|l|l}
\hline No & Kegiatan & $\begin{array}{l}\text { Indikator } \\
\text { Keberhasilan }\end{array}$ & $\begin{array}{l}\text { Hasil } \\
\text { Kegiatan }\end{array}$ & Evaluasi \\
\hline 1. & $\begin{array}{l}\text { Melakukan } \\
\text { psikoeduka }\end{array}$ & $\begin{array}{l}\text { Melakukan } \\
\text { penyuluhan }\end{array}$ & $\begin{array}{l}\text { Terciptanya } \\
\text { kesadaran }\end{array}$ & $\begin{array}{l}\text { Terlaksana(8 } \\
5 \%)\end{array}$ \\
\hline
\end{tabular}




\begin{tabular}{|c|c|c|c|c|}
\hline & $\begin{array}{l}\text { si tentang } \\
\text { covid-19. }\end{array}$ & $\begin{array}{l}\text { menggunakan } \\
\text { masker dan cuci } \\
\text { tangan. }\end{array}$ & $\begin{array}{l}\text { masyarakat } \\
\text { banding } \\
\text { agung akan } \\
\text { tentang } \\
\text { protokol } \\
\text { kesehatan. }\end{array}$ & \\
\hline 2. & $\begin{array}{l}\text { Pembagian } \\
\text { masker ke } \\
\text { masyarakat } \\
\text { desa } \\
\text { banding } \\
\text { agung. }\end{array}$ & $\begin{array}{l}\text { Memberikan } \\
\text { motivasi } \\
\text { masyarakat desa } \\
\text { banding agung agar } \\
\text { memakai masker } \\
\text { saat berpergian } \\
\text { keluar rumah. }\end{array}$ & $\begin{array}{l}\text { Masyarakat } \\
\text { banding } \\
\text { agung } \\
\text { termotivasi } \\
\text { untuk } \\
\text { menggunak } \\
\text { an masker } \\
\text { saat } \\
\text { bepergian } \\
\text { keluar } \\
\text { rumah. }\end{array}$ & $\begin{array}{l}\text { Terlaksana( } 8 \\
5 \%)\end{array}$ \\
\hline 3. & $\begin{array}{l}\text { Pemasanga } \\
\mathrm{n} \text { banner di } \\
6 \text { dusun } \\
\text { desa } \\
\text { banding } \\
\text { agung. }\end{array}$ & \begin{tabular}{l}
\multicolumn{2}{l}{ Terpasangnya } \\
banner tentang \\
gerakan \\
masyarakat hidup \\
sehat.
\end{tabular} & $\begin{array}{l}\text { Masyarakat } \\
\text { lebih } \\
\text { termotivasi } \\
\text { karena } \\
\text { adanya } \\
\text { banner } \\
\text { tentang } \\
\text { menjalanka } \\
\text { n protokol } \\
\text { kesehatan } \\
\text { sehingga } \\
\text { masyarakat } \\
\text { antusias } \\
\text { dengan } \\
\text { menerapkan } \\
\text { protokol } \\
\text { kesehatan. }\end{array}$ & $\begin{array}{l}\text { Terlaksana( } 8 \\
5 \%)\end{array}$ \\
\hline 4. & $\begin{array}{l}\text { Memberik } \\
\text { an } \\
\text { pemahama } \\
\text { n ke }\end{array}$ & $\begin{array}{l}\text { Melakukan } \\
\text { penyuluhan untuk } \\
\text { memotivasi } \\
\text { masyarakat }\end{array}$ & $\begin{array}{l}\text { Masyarakat } \\
\text { desa } \\
\text { banding } \\
\text { agung }\end{array}$ & $\begin{array}{l}\text { Terlaksana( } 8 \\
5 \%)\end{array}$ \\
\hline
\end{tabular}

Psikoedukasi Protokol Kesehatan dalam Mencegah Penyebaran Covid-19 di Desa Banding Agung 


\begin{tabular}{|c|c|c|c|c|}
\hline & $\begin{array}{l}\text { masyarakat } \\
\text { Desa } \\
\text { Banding } \\
\text { Agung } \\
\text { untuk } \\
\text { mengkons } \\
\text { umsi } \\
\text { makanan- } \\
\text { makanan } \\
\text { sehat yang } \\
\text { baik } \\
\text { dikonsums } \\
\text { i saat } \\
\text { masa } \\
\text { pandemic }\end{array}$ & $\begin{array}{l}\text { mengkonsumsi } \\
\text { makanan yang } \\
\text { sehat saat pandemi. }\end{array}$ & $\begin{array}{l}\text { termotivasi } \\
\text { untuk } \\
\text { mengkonsu } \\
\text { msi } \\
\text { makanan } \\
\text { sehat. }\end{array}$ & \\
\hline 5. & $\begin{array}{l}\text { Memberik } \\
\text { an } \\
\text { motivasi } \\
\text { ke } \\
\text { masyarakat } \\
\text { untuk } \\
\text { menjalank } \\
\text { an prokol } \\
\text { kesehatan. }\end{array}$ & $\begin{array}{lr}\text { Memotivasi } \\
\text { masyarakat untuk } \\
\text { tetap menjalankan } \\
\text { prokol kesehata } \\
\text { dengan } & \text { ketat } \\
\text { selama } & \text { masa } \\
\text { pandemi. } & \end{array}$ & $\begin{array}{l}\text { Sebagian } \\
\text { Masyarakat } \\
\text { sudah mulai } \\
\text { termotivasi } \\
\text { untuk selalu } \\
\text { menjalanka } \\
\text { n prokol } \\
\text { kesehatan }\end{array}$ & $\begin{array}{l}\text { Terlaksana }(8 \\
5 \%)\end{array}$ \\
\hline
\end{tabular}

Berdasarkan uraian tersebut program yang dilaksanakan untuk potensipotensi kedepannya pada masyakarat desa banding agung sebagai berikut :

1. Potensi Keberlanjutan

Aspek Terpenting di dalam kegiatan KKN-T ini adalah pada potensi keberlanjutan. Kegiatan ini dibuat berawal dari peneliti yang melihat sebuah permasalahan yang dihadapi selama masa pandemi covid-19, salah satunya masyarakat desa banding agung masih banyak yang belum paham tentang virus covid-19, sebagian besar masyarakat banyak tidak menggunakan masker saat berpergian keluar rumah,pergi ke kebun, dan kepasar, masyarakat 
perlu di motivasi sebagai pengembangan kognitifnya agar peduli dengan kesehatan di masa pandemic covid-19 ini.

Dari permasalahan yang ada, peneliti membahas suatu permasalahan dan memberikan solusi yaitu terbentuknya pemasangan banner gerakan hidup sehat dan pembagian masker di desa banding agung. Karena masyarakat masih banyak yang tidak menjalankan protokol kesehatan. Peneliti mengedukasi melalui penyuluhan untuk menjalankan protokol kesehatan agar masyarakat lebih peduli dengan kesehatannya selama masa pandemic covid-19 ini

Manfaat yang didapatkan dari program ini adalah meningkatnya kesadaran masyarakat di desa banding agung tentang adanya virus covid-19 dan memotivasi masyarakat untuk menjalankan protokol kesehatan dan mengkonsumsi makanan sehat Keberlanjutan program pengabdian masyarakat ini , juga mampu mendukung beberapa aspek kehidupan, seperti :

a. Aspek Ekonomi

Ketika sebagian masyarakat adalah sebagai petani dengan dibagikan masker, maka hal tersebut dapat dimanfaatkan secara ekonomi untuk memenuhi kebutuhan nya di tengah masa pandemi covid-19 ini.

b. Aspek Sosial dan Budaya

Ketika masyarakat mampu memahami dan mengembangkan kesadaran nya dengan cara menjalankan protokol kesehatan, maka hal tersebut mampu mencegah penyebaran virus covid19.

Psikoedukasi Protokol Kesehatan dalam Mencegah Penyebaran Covid-19 di Desa Banding Agung 


\section{KESIMPULAN}

Dengan adanya Kuliah Kerja Nyata Tematik (KKN-T) ini akan lebih membantu masyarakat agar lebih mementingkan kesehatan nya di tengah Pandemi Covid-19 ini dengan cara menjalankan protokol kesehatan dan juga mengkonsumsi makanan yang sehat . Karena Pandemi covid-19 ini sangat berbahaya jika kita tidak menjaga kesehatan , virus tersebut sudah banyak memakan korban jiwa.

Walaupun Program Kuliah Kerja Nyata Tematik (KKN-T) berjalan dengan lancar, namun ada beberapa kendala dan hambatan dalam pelaksanaan program, seperti cuaca yang tidak mendukung ,susahnya mengumpulkan masyarakat ketika ingin melakukan edukasi dikarenakan mayoritas penduduk desa Banding Agung adalah Petani.sehingga menjalankan kegiatan ini saat ada kegiatan di balai desa atau di posko covid-19.Semoga dalam kegiatan ini dapat memberikan manfaat bagi masyarakat di desa Banding Agung.

\section{E. UCAPAN TERIMA KASIH}

Penulis mengucapkan terimakasih yang mendalam kepada :

1. Dr. Sunda Ariana, M.Pd., M.M sebagai Rektor Universitas Bina Darma

2. Desy Arisandy, S.Psi.,M.Si.,Psikolog. Sebagai Dekan Fakultas Psikologi

3. Mutia Mawardah, S.Psi., M.A. sebagai Ketua Program Studi Fakultas Psikologi

4. Sawi Sujarwo, Spsi.,M.A sebagai Dosen pembimbing Keilmuan

5. Novri Hadinata, M.Kom sebagai Dosen Pembimbinng Lapangan 
6. Orang Tua yang sudah mendukung dan memberi semangat setiap saat.

7. Semua pihak yang turut serta membantu dalam kelancaran kegiatan KKN-T ini.

Penulis mengucapkan rasa terima kasih banyak atas segala doa dan dukungannya serta mohon maaf yang sebesar-besarnyajika terdapat kekurangan atas susunan Laporan Akhir KKN-T ini. Akhirnya penulis mengharapkan semoga Program Kreativitas Mahasiswa bidang Pengabdian Kepada Masyarakatini dapat memberikan manfaat bagi semua pihak, khususnya bagi penulis dan umumnya para orang tua.

Psikoedukasi Protokol Kesehatan dalam Mencegah Penyebaran Covid-19 di Desa Banding Agung 


\section{DAFTAR PUSTAKA}

Alfani, Hendra, Bambang Sulistyo, Akhmad Rosihan, dan Alip Susilowati Utama. 2019. "PENINGKATAN KAPASITAS PENGELOLAAN BADAN USAHA MILIK DESA SIPATUHU DALAM MENOPANG KAWASAN WISATA DANAU RANAU DI KAB. OGAN KOMERINGULU SELATAN.” Jurnal Pengabdian UntukMu NegeRI 3(2):118-26. doi: 10.37859/jpumri.v3i2.1427.

Anwar, Zainul, dan Maulida Rahmah. 2017. "Psikoedukasi Tentang Risiko Perkawinan Usia Muda untuk Menurunkan Intensi Pernikahan Dini pada Remaja." Psikologia: Jurnal Psikologi 1(1):1. doi: 10.21070/psikologia.v1i1.749.

Aslamiyah, Suaibatul dan Nurhayati. 2021. "Dampak Covid-19 terhadap Perubahan Psikologis, Sosial dan Ekonomi Pasien Covid-19 di Kelurahan Dendang, Langkat, Sumatera Utara." Jurnal Riset dan Pengabdian Masyarakat 1(1):56-69. doi: 10.22373/jrpm.v1i1.664.

Junaidi, J., Ramdhan, T. W., \& Putera, K. B. (2020). Membangun Ekonomi Pasca Covid 19 di Desa Sadah Tanah Merah Bangkalan melalui Pelatihan Pembuatan Keripik Kelapa. Dharma: Jurnal Pengabdian Masyarakat, 1(1), 17-27.

Kamil, Hutrin, dan Rezki Suci Qamaria. 2021. "Psikoedukasi Penerapan Kenormalan Baru di Masyarakat selama Masa Pandemi Covid-19 Berdasarkan Kajian Sosiologi Hukum dan Psikologi Hukum.” 13. Noviyanti, Irman Ari, dan . Lisnawati. 2019. "Perbedaan Psikoedukasi 'Tapis' Melalui Metode Latihan Gugus Tegas dan Persentasi Terhadap Pengetahuan Internet Sehat dan Aman Pada Orangtua." 89-105. 
Sofianto, Arif. 2021. "PEMAHAMAN DAN IMPLEMENTASI MASYARAKAT TENTANG PROTOKOL KESEHATAN COVID-19 DI JAWA TENGAH, INDONESIA.” 20(2):24.

Srivastava, Prashant, dan Rishi Panday. 2016. "Psychoeducation an Effective Tool as Treatment Modality in Mental Health." 4(1):8.

Sutinah. 2020. "Pelaksanaan Terapi Psikoedukasi Keluarga Terhadap Beban Dan Dukungan Keluarga.” Jurnal Ilmiah Pengabdian kepada Masyarakat 2(2):177-85.

Wahidah, Idah, Raihan Athallah, Nur Fitria Salsabila Hartono, M. Choerul Adlie Rafqie, dan Muhammad Andi Septiadi. 2020. "Pandemik COVID-19: Analisis Perencanaan Pemerintah dan Masyarakat dalam Berbagai Upaya Pencegahan.” Jurnal Manajemen dan Organisasi 11(3):179-88. doi: 10.29244/jmo.v11i3.31695.

Wiyati, Ruti, Dyah Wahyuningsih, dan Esti Dwi Widayanti. 2010. "PENGARUH PSIKOEDUKASI KELUARGA TERHADAP KEMAMPUAN KELUARGA DALAM MERAWAT KLIEN ISOLASI SOSIAL.” Jurnal Keperawatan Soedirman 5:10.

Psikoedukasi Protokol Kesehatan dalam Mencegah Penyebaran Covid-19 di Desa Banding Agung 